\title{
Entre Paulas, Martas, Pedros, Anas... para entender as complexas relações sujeitos/saberes no contexto da aprendizagem histórica
}

\author{
Among Paulas, Martas, Pedros, Anas... in order to understand \\ the complex subjects/knowledge relations in the context of \\ historical learning
}

\author{
Flávia Eloisa Caimi ${ }^{1}$ \\ Sandra Regina Ferreira de Oliveira ${ }^{2}$
}

RESUMO

Compreendemos a sala de aula como um espaço de entrecruzamento dos saberes de professores e alunos e permeado por interferências da sociedade na qual a escola esta inserida. O objetivo deste texto é conhecer a prática pedagógica de duas professoras quanto ao ensino de História nos Anos Iniciais do Ensino Fundamental para compreender como o trabalho que desenvolvem interfere na construção do conhecimento histórico dos alunos. A pesquisa na tipologia estudo de caso, contou com a participação de docentes de duas escolas municipais localizada na cidade de Londrina. Os dados, coletados por meio de observação em sala de aula e entrevista semi estruturada com as professoras, foram analisados a partir dos pressupostos teóricos anunciados por Isabel Barca, Hilary Cooper e Keity Barton. Concluímos que há semelhanças e diferenças quanto à prática das professoras e comportamento dos alunos nas duas salas de aula. De forma geral, o trabalho com a História baseia-se, quase que exclusivamente, na leitura do livro didático e na cobrança para que os alunos retenham as informações que este apresenta. Há um silenciamento frente aos questionamentos levantados pelos alunos quanto aos conteúdos e são inexistentes abordagens que possibilitem aos alunos compreenderem que o passado pode ter várias interpretações.

Palavras-chave: Ensino de história. Educação Histórica. Formação de professores. Aprendizagem histórica. Cotidiano Escolar.

\footnotetext{
1 Doutora em Educação pela UFRGS. Professora titular do curso de História e Programa de Pós Graduação em Educação na Universidade Passo Fundo/RS.

2 Doutora em Educação pela UNICAMP. Professora titular do curso de Pedagogia e Programa de Pós Graduação em Educação na Universidade Estadual de Londrina/PR.
} 


\begin{abstract}
We comprehend the learning room as a space where teachers and students knowledge cross it other, permeated by the idiosyncrasies from the society that surrounds the school. This study aims know the pedagogical practice of two teachers in the history teaching for the formers years of the fundamental school, to comprehend as the work that they develop interfere in the student's historical knowledge construction. The study of case method of survey had the contribution of the teachers of two municipal schools from Londrina. The data, collected through the observation inside the learning room and semi structured interviews with the teachers, were analyzed from the theoretical assumptions announced by Isabel Barca, Hilary Cooper and Keity Barton. We concluded that there are similarities and differences on the teacher's practice and the students behavior in both classrooms. From a general view, the work with the history is based, nearly exclusively, in the didactical book reading and in the demand to the students retain the information from it. There's a silence in front of the questions raised by the students about the content and the mechanisms that permit the students to comprehend that the past can have many interpretations are inexistent.
\end{abstract}

Keyword: History teaching. Historical education. Teacher's formation. Historical learning. Scholar everyday.

\title{
Introdução
}

Todas as ações desenroladas em uma sala de aula sustentam-se e podem ser analisadas a partir de três pontos, denominados de "tripé da relação didática", que são professor, aluno e saber. No espaço da sala de aula, segundo Lerner (1996, p. 95) o papel de cada ator é assumido publicamente, na medida em que "a criança se transforma em aluno [...] e o adulto, transforma-se em professor [...] e a relação que professor e aluno mantêm com o saber estão institucionalmente marcadas".

$\mathrm{Na}$ investigação que originou a produção dos dados que deram suporte para a construção deste artigo, a sala de aula foi entendida como um espaço de entrecruzamento dos saberes de professores e alunos, mediatizados tanto pelas propostas curriculares que ancoram o saber a ser transmitido quanto pelas influências e interferências da sociedade na qual a escola se insere. Para compreender todo esse movimento pedagógico, acompanhamos a dinâmica de funcionamento de duas turmas de terceira série dos anos iniciais do ensino fundamental, priorizando as relações que se estabelecem entre professor e saber, aluno e saber, professor e aluno e entre alunos e alunos, a partir dos conteúdos trabalhados pelas professoras das salas. São dois cenários diferenciados, com especificidades que influenciam diretamente a forma como os alunos constroem seus conhecimentos.

Selecionamos duas atividades de cada sala e analisamos a história que se ensina e se aprende. Ao sistematizar os dados da investigação no presente texto, utilizamos o recurso de 
descrever episódios das aulas, intercalando com análises sobre diferentes aspectos que auxiliam a compreender melhor o processo de construção do conhecimento que ali se colocou em ação.

Apoiamo-nos nas considerações de Costa (2002, p. 104) ao alertar sobre o direcionamento do olhar do pesquisador, que é "guiado por um desejo de conhecer que resulta na captura do objeto através da significação". As atividades aqui analisadas foram selecionadas, dentre tantas, para serem relatadas, na medida em que capturaram nosso olhar pela representatividade das situações carregadas de significados, as quais levaram a compreender a postura das professoras e dos alunos frente à aprendizagem da história.

As professoras, aqui nomeadas como Paula e Marta, são mulheres, trabalhadoras que carregam todos os seus desejos, anseios, vitórias e frustrações para a sala de aula. Algumas vezes conseguem bons resultados com seus alunos, outras vezes não. Todas as análises aqui apresentadas buscam entender as suas práticas pedagógicas não para classificá-las como certas ou erradas, mas para compreender como o trabalho que desenvolvem interfere na aprendizagem dos alunos, foco principal de nossas investigações.

\section{A sala de aula de Paula}

A Professora Paula está na faixa dos quarenta anos e fez o curso Normal Superior. É professora da rede municipal de ensino na cidade de Londrina há dezoito anos e já ministrou aulas para turmas multisseriadas na zona rural e para terceiras e quartas séries na zona urbana. Trabalha com a disciplina de História a partir da vida do aluno, da história dele, mas não sabe como fazer para que, ao estudar a história de Londrina, o aluno se sinta parte dela. Justifica que isso pode ser devido a uma falha na forma como ela trabalha, porque não consegue relacionar as histórias dos alunos com a história da cidade e acaba mesmo trabalhando esses elementos de forma separada.

Percebe claramente como os alunos vão aprendendo cada vez mais e melhor na escrita e na Matemática, mas não sabe explicar a ocorrência do mesmo processo na área de História. Acredita que para o aluno aprender História é necessário que saiba ler os textos e que visite os lugares estudados. Sua principal dificuldade no trabalho com a História é a falta de conhecimento sobre os assuntos, principalmente quanto à história de Londrina. Não raras vezes, trabalha somente com o conteúdo que o livro didático oferece e quase não tem tempo para procurar informações em outras fontes. Tenta levar $\mathrm{o}$ aluno a estabelecer relações entre o passado e o presente por meio da comparação entre as semelhanças e as diferenças, sem priorizar a memorização na aprendizagem. Paula assume que não fez nenhum 
planejamento para o ano letivo quanto ao trabalho a ser desenvolvido na disciplina de História.

Na sala de Paula há quatro meninas e nove meninos entre oito e doze anos. Somente um aluno frequenta a terceira série pela segunda vez e dois alunos vieram transferidos de outra escola. Os demais estudam juntos desde a primeira série. Na sequência, apresentamos fragmentos de episódios de sala de aula, intercalando-os com análises interpretativas.

\section{Atividade 1}

São oito horas de uma quinta feira. A aula é iniciada com um conflito entre Pedro e a professora. Pedro reclama que a polícia está em frente à escola para pegá-lo. Todos os alunos param perto da porta assustados. Paula diz que toda quinta-feira a patrulha escolar fica em frente à escola. Pedro diz que ontem ele estava na esquina, e a polícia tentou pegá-lo porque a professora auxiliar tinha mandado. Paula explica que uma professora não vai mandar a polícia pegar um aluno na rua. Após alguns minutos, Paula não liga mais para Pedro e entra na sala com os demais alunos. Logo após, Pedro entra também, bem mais calmo.

Sobre Pedro, a polícia e como Paula age em situações de conflito... Pedro tem doze anos e onze meses de idade. É o único aluno retido na terceira série. Sua permanência na escola é determinada por ordem da Promotoria da Infância, devido ao envolvimento em pequenos delitos. Como requer um atendimento especial, por solicitação da equipe pedagógica da escola, a Secretaria Municipal de Educação autorizou dividir a turma de terceira série em dois grupos, cada um com, no máximo, quinze alunos. Pedro também é acompanhado pela psicóloga que atende às escolas da rede municipal. $O$ que se pode perceber com relação a Pedro é que ele exerce certo poder na escola, porque os alunos e alguns professores demonstram ter medo dele. Não há nenhuma estratégia coletiva na escola para lidar com este aluno. Assim, ele acaba tendo autonomia para fazer o que quiser, desde que não atrapalhe os demais colegas.

Verificou-se, depois, que Pedro não fora abordado pela polícia na quarta-feira. Tratavase de uma encenação para chamar a atenção de todos. Paula não se envolve em discussões com os alunos. Raramente altera seu tom de voz e quando identifica que a conversa está caminhando para um conflito, deixa o aluno "falando sozinho", conforme suas palavras. Ao explicar como lida com a indisciplina de certos alunos, Paula deixa claro que não é bom envolver-se em brigas com os alunos "porque eles são crianças e se você entrar numa briga, você fica igual a eles". Prefere deixar a situação se acalmar para então intervir. Mas, "quando o assunto não é muito grave", na maioria das vezes, esquece-se de voltar a falar com o aluno. A postura de Paula faz com que o ambiente da sala de aula, apesar da existência de conflitos, 
não se caracterize por discussões entre professora e aluno. Os alunos demonstram respeito por Paula e esta pelos seus alunos.

Voltando à atividade... São oito horas e cinco minutos. Paula faz uma oração acompanhada por algumas crianças. Os alunos estão animados para a aula e comentam que gostaram da atividade de vôlei na terça à tarde. Cada um vai se dirigindo para o seu lugar.

Paula pendura no quadro um pano branco para projetar slides. Os alunos se animam: vamos ter historinha !!! Eles já sabem da atividade que será realizada porque a professora comentou no dia anterior. André atua como um secretário da professora, mesmo sem a sua solicitação, ajudando-a a colocar o aparelho de retroprojetor no lugar. Os demais alunos estão organizados em seus lugares, conversam baixinho entre si e, de certa forma, há uma situação bastante calma enquanto aguardam a projeção dos slides. Na verdade, não se trata de slides, mas sim de desenhos em transparência. Como o chão é de assoalho, qualquer passo faz com que a imagem projetada trepide bastante, o que causa risos. Combina-se que ninguém pode ficar andando na sala durante a projeção.

Antes de iniciar a projeção, Paula pega uma caixa e mostra para cada aluno, dizendo que dentro dela há um presente-surpresa. Trata-se de uma caixa embrulhada em papel vermelho, com um orifício no qual os alunos devem olhar para ver o "melhor presente do mundo". Paula passa de classe em classe para que os alunos olhem. Quem ainda não viu fica curioso, e quem já viu faz uma cara de alegria. Conforme os alunos vão olhando, Paula pergunta: achou bonito o presente? Viu que presente importante? Os alunos estão contentes, em seus lugares e esperam que todos olhem a caixa. Não houve tumultos, e ninguém estragou a brincadeira antes da hora, contando que dentro da caixa havia um espelho.

Sobre religião, sobre o André: todos os dias, no início da aula é feita uma oração católica, protagonizada pela professora que é católica. Na conversa que tivemos sobre a relação entre escola e religião, Paula diz que reza porque gosta, porque quer que Deus abençoe o seu trabalho. Nunca parou para refletir que possa ter alunos na sala que não são cristãos. Entende ser importante para as crianças acreditarem em Deus. Conforme suas palavras, nunca teve alunos ateus ou cujas crenças fossem "candomblé ou umbanda".

André tem um comportamento que se diferencia dos demais alunos da sala pela preocupação que demonstra ter pela professora. Está sempre ajudando, apagando o quadro ou carregando suas coisas. Durante as aulas, acompanha as atividades, mas demora um pouco mais que a média da sala. Fica irritado quando não consegue fazer alguma tarefa por causa da conversa dos colegas que já terminaram. Pede para que falem mais baixo.

Às oito horas e quarenta e cinco minutos, Paula guarda a caixa e conversa com os alunos: antigamente não tinha espelho. Como as pessoas faziam? Patrícia e Leandro (juntos): olhavam na água. Bruna: na história da Branca de Neve tem espelho. Paula: você 
conhece a história? Conta um pouquinho. Bruna conta. Fala sobre o espelho mágico da madrasta da Branca de Neve. Paula: Pois é, os bruxos utilizavam os espelhos para verem as coisas. Paula: Então vamos para a nossa história. É a história de um chinês que encontra um espelho na rua.

A primeira imagem projetada no slide é a do chinês olhando para o espelho e dizendo "papai". Os alunos não entendem por que o chinês diz "papai". A professora explica que ele não conhecia o espelho e achava que era o retrato do pai dele. Leandro: é burrice alguém não conhecer um espelho. Paula não comenta a informação. A história continua com mais três desenhos de pessoas se olhando no espelho pela primeira vez. $O$ último desenho retrata a importância e a beleza de cada pessoa. É uma história sem sentido, e os alunos ficam frustrados. Paula prossegue a aula.

Sobre o saber de Bruna e o saber de Paula, sobre o diálogo professora/alunos: Bruna é uma aluna muito inibida para falar. A professora afirma que tem "problemas de aprendizagem", principalmente quanto à leitura. Chama-nos a atenção como fica desinibida e conta a história em detalhes. Os colegas prestam-lhe muita atenção. Quando termina, indica a leitura do livro falando para todos que tem um na caixa da sala e outros na biblioteca.

No decorrer da atividade, Leandro fala: "é burrice alguém não conhecer um espelho". Tal informação indica um pensamento que não leva em consideração o fato do espelho não ter sempre existido. Ainda que a história não ajudasse muito na discussão, haveria possibilidade de engatar uma discussão sobre as diferenças entre os povos, entre as culturas. Além do mais, Leandro formula um pensamento anacrônico, porque julga o outro a partir dos pressupostos do seu tempo, o que também fornece elementos para discussões ricas para $o$ ensino e a aprendizagem da História.

Nos diálogos estabelecidos durante a atividade, a professora recebe as respostas, mas não busca identificar nos alunos como sabem a respeito para estabelecer uma relação entre o que eles já conhecem e o que estão prestes a conhecer. Deixa escapar uma temática muito interessante para ser aprofundada e que poderia ter vários desdobramentos: trabalho com reflexo, com o vidro, com a história do espelho. A relação estabelecida pela professora não causa discussão entre os alunos, que estão mais interessados em ver as imagens. No entanto, chamou nossa atenção a relação feita entre a realidade e a fantasia, pois quando a professora afirma que os bruxos utilizavam espelhos, ela já não o faz no contexto do faz de conta, no qual está inserida a história da Branca de Neve, e, com certeza, os alunos vão guardando estas informações.

A ligação entre os saberes dos alunos e o saber a ser ensinado, que, ainda timidamente a professora procurava estabelecer, é rompida no desenrolar da atividade. É fácil compreender o porquê. Tanto esse diálogo quanto a atividade com a caixa, não são 
considerados importantes no processo de aprendizagem. Eles são compreendidos como elementos motivadores que servem para iniciar uma temática, mas que depois saem de cena para que o conteúdo escolar tome o espaço da/na aprendizagem. É como se os alunos fossem convidados a falar sobre o que sabem e ouvissem um recado: "tudo bem, vocês sabem isso. Mas agora vamos para o saber de verdade, aquele que realmente tem importância".

No caso desta atividade, nem isso ocorre, porque a história que se segue, a do Kiki, o chinês, não apresenta novos conhecimentos para os alunos. Trata-se de uma situação montada para levar as crianças a discutirem sobre autoestima. Essas informações são coletadas depois da atividade, quando perguntamos à professora qual era o objetivo do trabalho com a história. Ela fala que é uma atividade de interpretação de textos e que aproveitou para falar da importância da pessoa gostar de si mesma. Quando afirmamos que seria uma atividade interessante para um trabalho com a História ela concorda, dizendo que poderia aprofundar pesquisando como eram os espelhos de antigamente e como são hoje.

Voltando à atividade. São nove horas. A professora escreve no quadro: Agora é com você. 1) $O$ que você achou da história de Kiki, o chinês? Justifique. 2) Você acha que nos dias de hoje, espelho é importante? Por quê? 3) Você costuma usar diariamente o espelho? 4) Quando você se olha no espelho, o que mais lhe chama atenção em seu rosto? 5) O que você sente quando vê sua imagem no espelho? Por quê? 6)Quando você percebe que alguém de sua família está triste, o que você diz para confortá-la?

Enquanto Paula está escrevendo as questões no quadro, os alunos vão copiando e conversando sobre outras coisas. Wilian diz que a festa junina poderia ser à noite (a festa seria no próximo sábado). José levanta e vai até o calendário para saber que dia é hoje. Olha no mês de setembro (estamos em junho). Leandro, que está prestando atenção em José, fala que ele está olhando no mês errado, que é para olhar em junho. Leandro pergunta se Paula já desligou o retroprojetor da tomada porque está escrito na etiqueta que é para desligar. Paula não toma conhecimento. Roberto levanta e desliga o aparelho. Alguém pergunta o que é "justifique". Paula explica. Diego pergunta o que é "diariamente". Paula explica. Todos os alunos copiam as questões e começam a responder. Como alguns alunos terminam rapidamente, Paula pede para que contem a história com suas próprias palavras. Bruna, Dalila, André e Joana terminam de escrever a história e ficam em pé em frente à mesa da professora para que esta corrija as questões. $O$ relógio da sala não está funcionando, marca cinco horas e cinco minutos. São nove horas e cinquenta minutos. Os alunos começam a andar pela sala, Paula continua corrigindo os cadernos dos alunos que vão até a sua mesa. Às dez horas, toca o sinal para o lanche. Os alunos saem correndo.

Sobre José, relações família-escola e explicações e correções... José, um aluno que apresenta dificuldades na leitura é muito quieto. Raramente solicita ajuda da professora ou dos amigos. Isola-se um pouco dos colegas. Às vezes, quando os colegas da sala o procuram, brinca um pouco, mas logo se afasta novamente. Paula avalia que José tem problemas na 
leitura e é muito tímido. José não faz as tarefas direito, a professora diz que "não há uma cobrança em casa", porque os pais trabalham fora e o aluno fica com a avó, mas os pais frequentam as reuniões, quando estas são à noite, o que de certa forma demonstra certo compromisso com a educação do filho. Como José não incomoda nem a professora nem os outros alunos, sua presença muitas vezes nem é notada. A professora explica que já solicitou à supervisão encaminhar o aluno para uma avaliação com a psicóloga.

Os alunos perguntam constantemente para a professora o significado de algumas palavras ou quando não entendem algo, como no caso da cena do espelho relatada anteriormente. Paula sempre responde. Nunca houve uma indicação por parte da professora para que os alunos buscassem o dicionário, ou que explicassem melhor o que não estavam compreendendo. Com o passar dos meses, se estabelece uma relação de dependência entre os alunos e a explicação da professora, e questões simples, que poderiam ser resolvidas sem sua interferência, são levadas pelos alunos até a professora para que ela explique o que é para ser feito. Essa postura de perguntar constantemente o que não entendeu está presente até nas provas, quando a professora explica, além do enunciado da questão, o que é para ser feito.

A correção dos cadernos durante as aulas é uma prática constante da professora. Os alunos vão terminando e levando o caderno até sua mesa, ou, então, ela passa de mesa em mesa corrigindo. Como, geralmente, quem já acabou se envolve em conversas paralelas, ou mesmo em brigas, sempre é "inventada" uma atividade extra, como, neste caso, escrever a história, ou como em outras situações presenciadas: desenhar, copiar uma parte do livro.

\section{Atividade 2}

São dez horas e vinte minutos de uma quarta-feira. Os alunos retornam do lanche e vão para os seus lugares. Na sala há vinte e cinco carteiras distribuídas em cinco colunas. Como são somente treze alunos, várias carteiras ficam vazias. Paula divide os alunos em dois grupos: verde e vermelho. No grupo vermelho ficam: Roberto, Wilian, André, Bruna, José e Joana. No outro, o verde, ficam: João, Leandro, Renan, Patrícia, Diego e Dalila. Pedro chega atrasado e sorteia o grupo vermelho, no qual está Joana, sua prima. A professora pede para que vá para o grupo verde, para não ficar junto com a prima. Pedro obedece. Será uma atividade de revisão para a prova de História e Geografia. No quadro é colocado um cartaz de cartolina com janelinhas numeradas de um a trinta. Explica o jogo: ela fará uma pergunta para um aluno. Se ele acertar, é ponto para a equipe. Se errar, sorteia um número e abre a janelinha do cartaz. Dentro das janelinhas há tarefas para serem cumpridas ou bombas. Se sair tarefa, o aluno tem que cumprir. Se cair bomba, ele está fora da atividade. $A$ atividade tem início. Paula: Bruna, o que é relevo? Agitação geral. Bruna: (fica vermelha)... é alto e 
baixo... é solo alto e baixo. Leandro (que é do outro grupo, interfere, aos gritos e com o dedo apontando para Bruna) Não é não! O relevo representa a irregularidade, os altos e baixos do solo. Paula: Muito bem, ponto para o grupo do Leandro. Bruna sorteia o número 18: imitar um pato. $O$ jogo continua. Leandro não consegue responder uma questão. Tira bomba, e os alunos fazem uma festa na sala, até mesmo os integrantes do seu grupo. Leandro não quer sair de jeito nenhum e causa a maior confusão. Paula quase chega a mudar as regras para que ele continue no grupo devido a tanta pressão que ele faz, mas os outros alunos ficam bravos e ela volta atrás. A atividade prossegue (reiniciando o jogo por três vezes). As perguntas formuladas são, dentre outras, no mesmo estilo: quem compôs o hino de Londrina? Quais são os símbolos municipais? Como era chamado o nosso município antes de ser Londrina? Como é o nome de nosso município? $O$ que é vegetação? $O$ que significa CTNP? Moramos e vivemos no estado do ...

Sobre Leandro, Pedro, Joana, Dalila, Bruna, José, sobre espaços e regras... Paula afirma não trabalhar de forma separada a História da Geografia. Utiliza um só caderno para as duas disciplinas e adota os dois livros, um completando o outro, conforme a necessidade do assunto.

Na sala de aula, não há uma reorganização do espaço, como empilhar as carteiras ou formação de grupos. A distribuição das carteiras é sempre em fileiras e, como há muitas que ficam vagas, os alunos trocam de lugar com frequência.

As regras para o jogo são modificadas no decorrer da atividade. Não havia sido combinado que o outro grupo poderia responder e nem que o ponto seria de quem respondesse no lugar do outro. Mas os alunos não percebem, ou não se incomodam com a situação e continuam participando.

Pedro e Joana moram juntos com a avó. Pedro exerce uma influência sobre Joana, que demonstra medo de errar quando está perto dele. Ao mesmo tempo, Joana procura Pedro para que este a proteja em algumas situações que envolvem outros colegas.

Leandro é um menino muito ativo. Entende as propostas com facilidade e faz as atividades em um tempo muito menor do que a maioria dos colegas. Quando termina, às vezes, ajuda os demais, passando de mesa em mesa. Outras vezes, atrapalha a todos com brincadeiras. Exerce certa liderança no grupo, porque todos o consideram "muito inteligente". No relacionamento com os colegas, gosta de dar ordens e fica irritado quando contrariado. É o único aluno da sala que vem à escola com relógio e, como o relógio da sala nunca funciona e a professora nem sempre está com relógio, controla o tempo, avisando a todos quanto tempo falta para o intervalo ou para saída.

Dalila é uma aluna muito quieta. Quando fala, sua voz é baixa e quase não dá para se ouvir. É a menor aluna da sala em tamanho, mas tem autoridade sobre todos. Sempre é 
procurada pelos colegas para dar sugestão sobre as atividades. É a única aluna com a qual Leandro e Pedro não fazem brincadeiras. Dalila demonstra irritação devido ao tempo que a professora demora na orientação das atividades e chega a perguntar para ela o que é para fazer. Quando a professora manda ler os livros da caixa, ela responde que já leu todos. Dalila começou a trazer livros de casa e, enquanto espera os colegas terminarem as atividades, fazia suas leituras.

Voltando à atividade. Às onze horas e quarenta e sete minutos, Paula termina a atividade, os alunos vão para os seus lugares. Paula passa algumas contas no quadro para esperar o sinal de saída.

\section{A sala de aula de Marta}

A professora Marta tem trinta anos e está na rede municipal de ensino há oito. Já trabalhou com pré-escola, segunda, terceira e quarta séries. É formada em Letras pela Universidade Estadual de Londrina e tem especialização em Psicopedagogia em Instituição Escolar, na mesma Universidade. Trabalha com a disciplina de História a partir da vivência de aluno e pensa que fazer passeios nos lugares a serem estudados sobre a História de Londrina é a melhor forma de levar os alunos a aprenderem.

Para ela, o mais importante para a criança é aprender sobre Londrina hoje, mas o passado deve ser estudado de forma sempre relacionada com o tempo presente, comparando o ontem e o hoje. O livro deve ser um material de apoio, e o professor precisa buscar outras fontes, por isso reclama que na escola não tem internet para fazer pesquisas. Ao analisar o seu trabalho com a disciplina de História, acredita que não avança muito devido ao fato de ter aprendido uma História de um jeito muito positivista, sempre mostrando o belo, o bonito, os heróis. Gostaria de ter a sua disposição mais recursos informatizados para trabalhar com os alunos. Marta, assim como Paula, também não fez um planejamento para o trabalho com a História durante o ano letivo. Na sala de Marta há sete meninos e quatro meninas entre oito e dez anos. Todos os alunos estudaram juntos na segunda série.

\section{Atividade 1}

São oito horas de uma terça-feira. O relógio da sala está parado, marca seis horas e quarenta e cinco minutos. Os alunos dirigem-se para os seus lugares. Na sala há vinte e cinco carteiras e somente onze alunos, portanto, várias carteiras ficam vazias. Marta começa a 
aula rezando a oração do Pai Nosso, mas os alunos não a acompanham, estão conversando e andando pela sala. A atividade será uma revisão para a prova de História. Marta pede para que os alunos leiam a página 55 do livro didático, em que há um pequeno texto e cinco questões. Começa perguntando: como foi a viagem de Smith? Um aluno: foi cansada (talvez queira dizer cansativa). Marta: não é só isso. Gente, vocês não leram o livro? Olha a interpretação! Henrique: foi em 1929. Marta: isso mesmo. Muito bem! Foi em 1929. Que rio eles atravessaram? Mateus: o Tibagi. Marta: o que vocês entendem por "majestoso"? Silêncio na sala. Marta explica que é grande, imenso. Mateus: mas o Tibagi não é grande. $O$ Paranapanema é maior.

Sobre Henrique, Mateus, tempo, relógios, interpretações e novamente religião... Conforme a professora, o trabalho com a disciplina de História é realizado separadamente do trabalho com Geografia, por julgar mais fácil trabalhar "uma coisa de cada vez". Marta, na busca de conseguir melhores resultados de aprendizagem junto aos alunos, faz muitas cobranças: se não sabe responder é porque não leu o texto; se não fez a tarefa é porque não tem responsabilidade, se tirou nota ruim na prova é porque não estudou. Desta forma, a responsabilidade pela aprendizagem é sempre colocada numa ação do aluno. Marta tenta levar os alunos a refletirem sobre as palavras que não conhecem, sem dar o significado num primeiro momento. Mas, como não obtém resposta, desiste instantes depois, formulando respostas para suas próprias perguntas. Isto é constante em suas aulas: faz perguntas para os alunos, mas ela mesma as responde.

Relógio sem funcionar é uma constante na escola. Todas as salas têm relógio, mas somente os da cozinha e da sala de professores funcionam. Quando a professora estabelece que a atividade terá tantos minutos, e esta é uma prática de Marta, apesar de nem sempre cumprir suas promessas, os alunos que não possuem relógio não têm como se orientar no tempo. Alguns alunos se preocupam com o tempo estabelecido e ficam perguntando para a professora, ou para um colega, sobre quanto tempo falta. A maioria, no entanto, despreza totalmente a questão do tempo e faz as atividades no seu próprio ritmo.

Sobre a oração no início da aula, Marta afirma que reza porque na escola tem um tipo de "ensino religioso" no qual todas as religiões são trabalhadas com respeito. Foca-se o respeito à natureza, a Deus, ao próximo, "independente do aluno ser da umbanda, da religião espírita. Na minha sala são todos cristãos e o Pai Nosso não é uma oração católica, é universal porque traz a palavra de Deus. Se o aluno não quiser rezar, fica à vontade. Pede "com licença, eu não vou fazer a oração". "Eu respeito."

Henrique é um aluno que apresenta dificuldades para ler e para se expressar frente aos colegas. Apega-se aos mínimos detalhes durante as atividades ficando, às vezes, muito tempo melhorando um desenho. Quase nunca arrisca responder às perguntas da professora em voz alta, mas o faz em voz bem baixinha. 
Mateus é um aluno que gosta de responder às questões da professora e participar da aula. Mora em uma chácara, próximo ao Rio Tibagi e conta muitas histórias sobre o seu diaa-dia, principalmente sobre suas pescarias. Está sempre atento às aulas e relaciona-se bem com todos os colegas. A relação que este aluno estabelece é bastante interessante. Como conhece o Rio Tibagi, sabe que ele não representa mais um obstáculo natural para o homem, como representava em 1929. Além do mais, realmente, o Rio Paranapanema é maior do que o Rio Tibagi. Marta não explora esta relação que seria um excelente ponto de partida para discutir dentre outras questões: como um mesmo rio pode representar diferentes coisas para homens de diferentes tempos.

Voltando à atividade. Às nove horas a revisão termina. Marta dá um tempo para que os alunos estudem um pouco mais para a prova que será logo a seguir. Alguns alunos fazem a leitura do texto, outros ficam sentados folheando o livro ou mexendo em seus pertences. Às nove horas e vinte minutos, Marta entrega a prova para os alunos. As questões são as mesmas da revisão.

Sobre provas... A prova é de História e Geografia e é a mesma para as duas terceiras séries. O resultado dos alunos não é animador em ambas as turmas. A média geral da sala de Marta é $50 \%$ e a de Paula $60 \%$. As professoras ficam arrasadas e comentam: (Paula) como os alunos podem errar questões tão fáceis? (Marta) E olha que fizemos uma revisão antes da prova. Verificando as provas, uma a uma, percebemos que, no grupo da Professora Marta, alguns alunos vão muito bem, acertam quase tudo, mas outros não acertam nada ou quase nada. Há uma disparidade entre os que conseguem e os que não conseguem e não há um grupo intermediário. Os alunos que têm dificuldade para ler não fazem quase nada, porque ela não lê a prova para eles. Acha que se trata de uma atividade individual e que não deve estar lendo porque "senão eles nunca vão fazer nada sozinhos". Na sala de Paula, o resultado é mais equilibrado. Não há nenhum aluno que acerta tudo, mas também nenhum que erra tudo, e há uma boa parte de alunos que se situam numa faixa intermediária. É importante destacar que Paula lê a prova para os seus alunos, o que interfere diretamente nos resultados.

Voltando à atividade. Às dez horas, conforme os alunos vão terminando a prova, e alguns terminam em menos de quinze minutos, Marta pede para que fiquem lendo o livro de História.

\section{Atividade 2}


São oito horas de uma quinta-feira. Marta começa a aula, rezando com os alunos. Vão trabalhar com uma atividade de História. É conteúdo novo, e Marta já avisa que na próxima aula terá prova com este conteúdo. No quadro escreve:

História

Escola ...

Londrina ...

Assunto: "Será que todas as pessoas chegaram da mesma maneira a Londrina?" (trata-se de um tópico do livro didático). Ler silenciosamente as páginas 58 e 59.

Às oito horas e dez minutos distribui os livros e avisa aos alunos que eles devem ler para interagir porque uma aula não é ela falando sozinha. Marcou, verbalmente, um tempo de 10 minutos para a leitura do texto. São somente três fragmentos de textos (cerca de 20 linhas) nas duas páginas assinaladas. No mais, são propostas de atividade para serem realizadas em casa e na sala de aula. Enquanto os alunos fazem a leitura, passa o recado da entrega de um bilhete para escolha do Conselho Escolar. Os alunos param de ler para olhar o bilhete.

Sobre o tempo (novamente), e interrupções... Não há como os alunos controlarem o tempo porque o relógio da sala não funciona, mas destaca-se o fato de Marta tentar estipular um tempo igual para todos, o que leva o aluno a descentrar-se de seu próprio ritmo e tentar acompanhar um ritmo coletivo.

A interferência da professora, diretora ou supervisora, quando os alunos estão em atividade, é constante em sala de aula. Muitas vezes, a professora acaba de orientar os alunos sobre a necessidade de atenção, de concentração, e quando eles iniciam a atividade são interrompidos com algum recado ou algum comentário feito por ela.

Voltando às atividades. São oito horas e vinte minutos. Muitos alunos já acabaram a leitura, mas Marta marca um novo tempo limite no quadro: até às oito horas e trinta minutos. Durante o tempo em que os alunos estão lendo (alguns), Marta fica sentada em sua mesa com um fichário aberto, copiando algumas coisas em seu caderno. Abre o livro de História e faz algumas anotações. Alguns alunos continuam lendo. Henrique e Ana estão copiando as frases que foram escritas no quadro (não ficou claro se era ou não para copiar no caderno). Luís ainda não abriu o livro. Mateus (para a professora): Em 1934 era bom. Podia dormir de porta aberta e nem tinha ladrão. Marta (sem tirar os olhos de seu caderno): Era 
bom, né? Muita coisa mudou para pior. Mateus e Fábio começam a conversar sobre as gravuras que aparecem no livro.

Sobre Henrique, Ana, relação entre passado e presente... Henrique e Ana são os alunos que apresentam maior dificuldade com a leitura e a escrita. Por isso demoram muito para copiar as coisas do quadro.

No texto há uma informação sobre o ano de 1934 que não faz nenhuma referência a "ladrões" ou a "tempos bons". Esta ideia de passado como tempo bom aparece com frequência na fala das crianças. A professora reafirma esta noção ao fazer um comentário sem contextualizar historicamente: o que era bom? Por quê? Para quem era bom? Tudo era melhor do que hoje? Também perdeu a oportunidade de levantar por que o aluno estabelece esta relação.

Voltando às atividades. São oito horas e trinta minutos e Ana continua copiando as frases do quadro. Marcelo (para a professora): Londrina antigamente se chamava pequena Londres? Professora: Leia direito no livro. Não é bem assim. Por que tinha esse nome? Marcelo: Porque é filha de Londres. A professora não prossegue a discussão. Às oito horas e quarenta minutos, dez minutos além do combinado, Marta se levanta, dirige-se para o centro da sala e inicia o diálogo com os alunos: Marta: Por que José veio para Londrina? Alguns alunos em coro: Para trabalhar na oficina. Marta: como ele chegou aqui? Em coro: De barco. Marta: Qual a diferença entre... Leandro (interrompendo): não, professora. Ele veio de caminhão e de balsa. Marta: Isso mesmo (no texto diz que José Ziober fez a viagem de caminhão até Ourinhos, de trem até Jataizinho, de balsa na travessia do Rio Tibagi e de ônibus até Londrina). Qual a diferença entre a viagem de Smith e de José Ziober? Silêncio. Marta: a viagem de Ziober não foi tão difícil, né? Vocês não lembram da viagem do Smith. Vamos ler de novo a página 55. Faz a leitura. Ana e Cléo não estão com o livro aberto na mesma página que a professora está fazendo a leitura. Marta estabelece, ela própria, a relação entre as duas viagens.

Às oito horas e cinquenta minutos a diretora entra na sala para avisar que o pessoal do teatro está pronto. Marta avisa aos alunos para deixarem os livros sobre a mesa porque vão ao teatro. Os alunos ficam felizes. Trata-se de um teatro de marionetes sobre a Dengue, com o cenário montado no pátio. Os alunos ficam bem quietos no início, mas após uns cinco minutos já estão inquietos, conversando entre si e olhando para trás. $O$ teatro é realmente cansativo e sem graça. Na verdade, é uma palestra com marionetes.

Às nove horas, as crianças já não demonstram nenhum interesse pelo teatro. Marcelo e Ana começam a se desentender. Mateus se espicha no banco, incomodando os outros colegas. Marta está atenta ao teatro e desatenta com seus alunos. Às nove horas e dez minutos voltam para sala, e nenhum comentário é feito sobre o teatro. Marta pede para que os alunos leiam novamente a página 55. Somente Carla começa a fazer a leitura. Marcelo e 
Ana continuam discutindo (o mesmo assunto que começou lá no teatro), Leandro está deitado com a cabeça sobre o livro, Fábio, Mateus e Luís conversam e Cléo está olhando pela janela. A diretora entra novamente na sala para conversar com a professora. Não sei o assunto. Às nove horas e quinze minutos Marta começa novamente o questionamento, sem considerar que os alunos não fizeram a leitura. Ela mesma faz perguntas e as responde. Às nove horas e vinte e cinco minutos, passa as questões no quadro, as mesmas que estão no livro didático. Pede para que os alunos copiem a questão no caderno e respondam em voz alta, todos juntos, para que ela possa escrever a resposta "certinha" no quadro para todos copiarem.

Por que José Ziober veio para Londrina?

Resposta - Porque o irmão dele instalou uma oficina e ele veio trabalhar aqui.

Quais meios de transporte utilizou para chegar a Londrina?

Resposta - Caminhão, trem, balsa e ônibus.

Somente Mateus e Fábio estão respondendo às questões em voz alta. Os demais se limitam a copiar as respostas do quadro. Após a segunda questão, Marta passa de mesa em mesa para ver se os alunos estão copiando. Pára na mesa de Ana. Marta: Pelo menos você copiou a pergunta? Ana responde que sim. A professora incentiva os alunos a colorirem os cadernos. Mateus pintou de preto algumas coisas e mostra para a professora. Marta: Preto é muito feio. Marta: Ao passar pela mesa de Carla - muito bem, Carla. Seu caderno está organizado e sua letra muito bonita. Marta: para Marcelo - Muito bem, você está se esforçando. "Tudo posso naquele que me fortalece".

Sobre Ana e mais uma vez, sobre religião... As ações de Marta demonstram que ela já "desistiu" de Ana. Quando conversamos sobre a aluna, relata que Ana não tem mais jeito, que a família não apóia, que ela ainda não aprendeu a ler direito. Falo para Marta que Ana gosta muito de histórias e como pode ler os livros e contar as histórias sem saber ler. Marta diz que não sabe, que alguém deve ler para ela.

Marta usa muitas frases religiosas para se comunicar com os alunos; sempre que pode fala de Deus. No caderno dos alunos há várias frases copiadas do quadro, como: "Em Deus faremos proezas (Salmo 60, 12)", "Entrega teu caminho ao Senhor, confia nele e o mais ele fará (Salmo 37,5)" (Não busquei verificar a origem dos salmos). Percebe-se que, para a professora, ser bom cidadão é ser bom cristão, e ela faz vários "sermões" para os alunos neste sentido. Quando conversamos sobre o assunto, Marta explica: "alguma coisa essas crianças precisam ouvir de bom. Eles só falam em novela, de televisão, só têm informações negativas. Então, se eu puder passar coisas positivas para eles, eu passo. Não é só falar, é fazer também. Nós somos espelhos para nossos alunos". Comentamos que ela não tem 
conseguido disciplina com seus alunos por meio dos sermões e que, na sala, muitas vezes chega-se a uma situação de exaustão. Marta concorda e completa: "olha, a minha turma tem um problema muito sério de auto-estima, eu estou tentando me doar, fazer o melhor, mas algumas vezes fico desanimada".

Voltando à atividade. Às nove horas e quarenta minutos passa-se para a letra "c": C) Quais são as diferenças entre a viagem de George Craigh Smith e de José Ziober? (É Mateus quem responde novamente e sua resposta vai para o quadro). Resposta - A Viagem de George Craigh Smith foi mais sacrificante do que a viagem de José Ziober, além do polonês utilizar mais meios de transporte do que o inglês.

Uma aluna da outra terceira série vem pegar giz emprestado. Ana fala para a professora que Fábio disse que a menina era feia. A professora diz que ninguém é feio, pois somos todos feitos "à imagem e semelhança do papai do céu". Os alunos começam a conversar sobre quem é feio e quem é bonito. A professora pergunta se conhecem a história da Bela e da Fera. Ana conhece e conta uma parte da história para o grupo, com muito entusiasmo. Os alunos pedem para que a professora passe o filme para eles. Marta diz que tem outra história sobre ser feio ou bonito, a do Patinho Feio. Ana novamente diz que conhece e conta uma parte da história. Somente Mateus continua fazendo as questões do livro de História, todos os demais já estão envolvidos pela discussão do feio e bonito. A professora, a partir da discussão sobre a beleza faz um "sermão" sobre a importância dos valores espirituais, sobre amar a Deus sobre todas as coisas, que Deus vai cobrar se você foi bom filho, boa professora. Mateus, que acabou de fazer as questões, pergunta se é verdade que quando "a gente é feio quando é pequeno, cresce e fica bonito". Todos caem no riso.

Às dez horas Marta pede para que os alunos copiem do livro a questão "d". Enquanto os alunos estão copiando a questão, anda entre as filas e carteiras e fala sobre diversos assuntos. Afirma que gosta muito de seus alunos, que só não gosta deles quando fazem coisas que apagam a luz do coração. Mateus diz que não quer ser professor porque dá muito trabalho e ganha pouco. Marta diz que é verdade, mas ela ama o que faz. Há uma desatenção geral na sala, os alunos estão cansados e se levantam constantemente. A questão "d" é: Quais são as diferenças entre a Londrina que George Craigh Smith e seus companheiros viram e a que José Ziober viu? O que era parecido?

Marcelo e Fábio perguntam se estas pessoas já morreram. A professora diz que sim. A resposta que Marta coloca no quadro é assim: A diferença foi que Londrina não era habitada e era floresta quando George chegou, mas quando José veio [a cidade] (pede para os alunos apagarem 'a cidade' e colocarem do jeito que está no livro) as casas era de palmito e tinham lampião. $O$ que era parecido é que aqui tinha ruas cheias de tocos e buracos.

Avisa que quem for terminando é para desenhar os meios de transporte. Alguns alunos estão fazendo os desenhos que a professora pediu. Outros estão conversando entre si. Com o 
passar dos minutos, a bagunça vai se generalizando pela sala. A professora chama atenção dos alunos e ameaça chamar de dois em dois para sair para o lanche. Às dez horas e vinte minutos bate o sinal para o lanche. Marta consegue chamar somente o nome de dois alunos. Logo a seguir todos os demais saem correndo para lanchar. Assim terminam duas horas e vinte minutos de atividade com História.

Sobre biografias e as "visões" cristalizadas da História... As crianças demonstram muito interesse pela vida das pessoas que são citadas no texto. Querem saber quem são, como viviam, se estão vivas etc.

A professora reafirma a ideia de que não havia ninguém nas terras quando os ingleses chegaram, desconsiderando a questão dos povos indígenas que o próprio livro didático apresenta nos capítulos anteriores. Faz-se interessante destacar que ela se preocupou muito mais em arrumar a informação sobre a cidade e as casas do que sobre os indígenas. Quando conversamos sobre o assunto ela fica surpresa: "Nossa, como deixei passar isso. Nem tava no texto".

\section{Algumas considerações sobre ensinar e aprender História}

Nas duas salas de aula há semelhanças e diferenças quanto à prática das professoras e comportamento dos alunos. A partir dos dados apresentados nas cenas selecionadas, vários enfoques poderiam ser destacados para analisarmos estas semelhanças e diferenças e como interferem no processo de aprendizagem dos alunos envolvidos. Devido ao recorte proposto para este texto, limitamo-nos a refletir sobre a História que se ensina e se aprende em sala de aula.

O trabalho com o ensino e a aprendizagem da História deve se dedicar "a entender as ideias, estratégias cognitivas e progressão de pensamento dos sujeitos que aprendem e ensinam história" (BARCA, 2001, p. 7), inseridos em um contexto demarcado por regras estruturantes próprias, que conferem características peculiares e possibilitam diferentes construções sobre o que seja a História e qual a sua finalidade na educação de crianças.

Os alunos e as professoras que fazem parte desta pesquisa estão inseridos em uma realidade escolar na qual o trabalho com a História baseia-se, quase que exclusivamente, na leitura do livro didático e na retenção das informações que este apresenta. Convém ressaltar que não é só o trabalho com a História que possui essa característica, todas as áreas do conhecimento são abordadas desta forma. 
O conteúdo de História trabalhado na sala de aula da $3^{\text {a }}$ série é baseado exclusivamente no livro didático, porque as professoras afirmam não terem conhecimentos e materiais suficientes para trabalharem de outra forma. Portanto, é o conteúdo que está no livro que será trabalhado junto aos alunos, mas reinterpretado segundo os saberes que os professores carregam há muito tempo, oriundos de sua escolarização, de sua vida e suas experiências. Foi o que pôde ser percebido quando uma das professoras escreve no quadro que Londrina não era habitada à época em que George Smith chegou, mesmo que o livro indique, pelo contrário, a presença dos povos indígenas na região, naquele período (TUMA, 2001, p. 38-47). Explicações para essas situações ocorridas no cotidiano escolar podem ser encontradas em autores como Tardif (2002), que apresenta, em seus resultados de pesquisas, como o saber da experiência é mais valorizado pelos professores, e em pesquisa como a de Miranda (2008) que demonstra a relação existente entre a cultura do lugar e os saberes que os professores constroem sobre a História a ser ensinada.

Se a prerrogativa anunciada acima sobre os saberes dos professores for considerada, convém admitir que qualquer trabalho que vise discutir com os professores sobre o processo de ensino e aprendizagem de História e o que se pretende com o mesmo, precisa partir de uma retomada com o professor sobre o que ele aprendeu sobre História, de onde vem esse saber, como e por que esse saber foi alçado à categoria de verdade, como este saber é/foi influenciado pela cultura na qual está inserido e como esse saber é mobilizado, cotidianamente, em sua prática pedagógica.

Nas salas de aula observadas, o objetivo com o ensino de História é levar os alunos a memorizarem as informações apresentadas no livro didático. Mesmo quando algumas propostas buscam motivar os alunos à participação, como os jogos, a finalidade é levar os alunos a memorizarem determinados assuntos abordados no livro didático. Dessa forma, outros caminhos que seriam interessantes para o trabalho com a História não são trilhados, apesar das oportunidades criadas no próprio contexto da aula como, por exemplo, em uma atividade sobre uma lenda a respeito do espelho, um aluno fala que é "burrice alguém não saber o que é um espelho". As professoras demonstram não conhecer uma forma de relacionar a fantasia e a realidade e como uma pode ser possibilidade para o trabalho com a outra, conforme destaca Cooper (2002).

Nas atividades, em que realidade e fantasia se misturam, os alunos podem se identificar com os personagens e fazer deduções a partir das relações que se estabelecem na história (COOPER, 2002, p. 84). A partir desse ponto, são várias as possibilidades que se abrem para um trabalho que traz resultados diretos para o que se pretende com o ensino de História, como a comparação entre diferentes versões de uma mesma história, de temas similares, em diferentes culturas (COOPER, 2002, p. 90).

Ainda segundo Cooper (2002, p. 96), a partir do contato dos alunos com diversas histórias, na medida em que crescem e ampliam seus conhecimentos, podem dedicar-se a 
descobrir mais sobre o que já se conhece. De uma atividade de imaginação, pode-se chegar a uma imaginação histórica válida. Isso pode levar, mais adiante, à construção de uma empatia histórica, à compreensão de como as pessoas do passado pensavam e por que se comportavam de forma tão diferente da nossa, compreendendo os aspectos sociais, econômicos e políticos das diferentes sociedades.

Possibilidades semelhantes para se abordar questões que levariam os alunos a aprender sobre o estatuto da História aparecem em outros trabalhos, como quando Mateus não aceita a característica "majestoso" para o rio Tibagi, dentre tantos outros exemplos que poderiam ser pinçados das aulas observadas. As professoras não se detêm a estas possibilidades porque, diferente do que ocorre com as disciplinas de Língua Portuguesa e Matemática, por exemplo, não há uma compreensão clara sobre como o aluno pode avançar no conhecimento da História. Isso pode dar indícios para compreender melhor por que o trabalho com a História, assim que deixa de tratar sobre as memórias familiares, segue sempre a mesma rotina, desde a terceira série do ensino fundamental até a última série do ensino médio: ler os textos, às vezes, interpretá-los e, sempre, memorizar as informações para serem repetidas em avaliações.

Nas atividades presenciadas, em todas as áreas do conhecimento, percebe-se que em alguns momentos o professor conversa sobre os saberes dos alunos antes de iniciar um novo conteúdo, mas as informações coletadas junto à turma são descartadas logo que o saber escolar começa a ser explicitado. É como se fosse falado para os alunos: que bom que vocês sabem essas coisas, mas devem aprender coisas diferentes sobre o assunto. Assim, não se estabelece uma relação significativa entre o saber a ser ensinado e o saber que o aluno já possui. Por isso, ele não estabelece relações entre um e outro e, em grande parte, desconsidera com o passar do tempo o saber escolar, ficando somente com o saber que para ele possui algum significado e que geralmente foi construído fora dos muros escolares, conforme destacou Barton (2001), em sua pesquisa com crianças dos Estados Unidos e da Irlanda do Norte.

Nas aulas presenciadas, os professores não organizam as atividades de forma que os alunos tenham oportunidade de formular hipóteses, de buscar provas, de discutir alternativas, de trocar suas hipóteses e aperfeiçoar os conceitos que possam estar aprendendo (COOPER, 2002, p. 72). Isso não significa que os alunos não façam tais procedimentos. Fazem no espaço e no tempo de transgressão, principalmente no tempo em que as professoras estão corrigindo os cadernos. Mas, como fazem as trocas sem a mediação da professora, apenas na interação com os colegas, essas trocas ficam no nível do que já conhecem, do que são capazes de relacionar.

Nas atividades de leitura de textos, metodologia mais frequente no trabalho com a História, os alunos raramente apresentam dúvidas. Isso contribui para que a criança conceba uma ideia de História objetiva, que dificilmente será revertida nas séries 
posteriores. Nega-se, portanto, a possibilidade do aluno compreender que o passado pode ter várias interpretações, porque este não é incitado a elaborar suas próprias conclusões baseando-se no que sabe e no que pode vir a saber a partir do material oferecido pelo professor.

Por fim, destacamos que, ao observar o cotidiano da sala de aula, percebe-se como os alunos gostam da convivência com os colegas, de dialogar, de trocar informações e, nas raras vezes em que o conhecimento incitava o aluno a estabelecer relações, ou seja, quando este se tornava significativo, o interesse era geral. Em síntese, os alunos querem e gostam de aprender História na escola. Nosso desafio, como professores, é saber explorar essas potencialidades.

\section{Referências}

BARCA, Isabel (Org.). Perspectivas em educação histórica. Centro de Estudos em Educação e Psicologia/Instituto de Educação e Psicologia/Universidade do Minho, 2001.

. O pensamento histórico nos jovens. Braga: Universidade do Minho, 2000.

BARTON, Keith. Idéias das crianças acerca da mudança através dos tempos: resultados de investigação nos Estados Unidos e na Irlanda do Norte. In: BARCA, Isabel (Org.). Perspectivas em educação histórica. Centro de Estudos em Educação e Psicologia/Instituto de Educação e Psicologia/Universidade do Minho. 2001. p. 55-68.

COOPER, Hilary. Didáctica de la história em la educación infantil y primária. Madrid: Morata: 2002.

COSTA, Marisa Vorraber (Org.). Caminhos investigativos II: outros modelos de pensar e fazer pesquisa em educação. Rio de Janeiro: DP\&A, 2002.

LERNER, Delia. O ensino e o aprendizado escolar. Argumentos contra uma falsa oposição. In: CASTORINA, J. A. et al. Piaget - Vygotsky: novas contribuições para o debate. São Paulo: Ática, 1996. p. 85-146.

MIRANDA, Sonia Regina. Sob o signo da memória: cultura escolar, saberes docentes e história ensinada. São Paulo: UNESP/UFJF, 2008.

TARDIF, Maurice. Saberes docentes e formação profissional. Petrópolis: Vozes, 2002.

TUMA, Magda Madalena. Viver é descobrir: história. São Paulo: FTD, 2001. 